\title{
Antecedents of Online Purchase Decisions : An Evidence from Indonesia
}

\author{
Mohamad Najmudin* Titop Dwiwinarno Erni Ummi Hasanah \\ Faculty of Economics and Business, Universitas Janabadra, Jalan Tentara Rakyat Mataram 57, Yogyakarta \\ 55231, Indonesia
}

\begin{abstract}
This study aimed to explain the influence of social media and price perceptions on online purchase decisions mediated by purchase interest. The sample used was 260 respondents who were taken by accidental sampling technique. The collected data was then analyzed using structural equation modelling (SEM). The results show that social media and price perception have a direct effect on purchase decisions. In addition, social media and price perceptions affect purchase decisions through the mediation of purchase interest. The regression coefficient shows that social media has more influence on purchase interest than its effect on purchase decisions. Meanwhile, price perception has more impact on purchase decisions than its effect on purchase interest.
\end{abstract}

Keywords: Purchase decisions, purchase interest, social media and price perception

DOI: $10.7176 / \mathrm{JESD} / 12-22-03$

Publication date: November $30^{\text {th }} 2021$

\section{INTRODUCTION}

Today, information technology plays a critical role in all aspects of human life. By mastering technology and information, we have sufficient capital to be a winner in global competition. According to Miarso (2007), technology has the meaning of a process to increase added value. The process uses or produces a product; the resulting product is not separated from other existing products and becomes an integral part of a system. So it can be concluded that the era of technology is when products are always recycled or created to meet human needs. One of the uses of technology that is developing at this time is the purchase of products online.

As we already know, along with the development of technology and information, many online shops have sprung up in various circles, from teenagers to adults. The goods offered are also different, ranging from food, household equipment, lifestyle, automotive, electronics, etc. These items are sold online through websites, social media accounts and online stores in various marketplaces.

The main difference between online shopping and in-store purchases is the ability of potential buyers to evaluate a product so that it can generate buying interest and purchase decisions. In online shopping, prospective buyers cannot directly check the goods they want to buy and are usually only assisted by pictures or descriptions provided by the seller. At the same time, in retail stores, we can easily see or physically touch the goods. Therefore, one of the essential factors that customers consider when purchasing online shopping is price. The purchase decision is a process in an actual purchase, whether to buy or not. According to Kotler \& Amstron (2007), purchasing decisions are the stage in the buying decision-making process where consumers will buy. So by knowing what consumers are considering, the company will offer what consumers need and want so that it can be implemented on target and sales can be achieved.

Promotion through social media effectively stimulates attention, but it is still not practical at the interest, desire, and action (Philip Kotler et al., 2019). Social media is very suitable for attracting users' attention to know various information, especially from a product. However, it is still unlikely for someone to purchase the product being informed of the act of purchasing. Factors for making purchases are not only from social media but also from product quality or consumer perceptions of prices. The function and role of social media have changed the way a person communicates, which was initially one-way and two-way, has now become all-way. It can also be an important channel for retailers to connect with consumer opinions and get the general public to solve new products and services problems.Persepsi konsumen pada dasarnya dipengaruhi oleh rangsangan fisik yang berhubungan dengan lingkungan sekitar dan keadaan individu yang bersangkutan. Persepsi harga merupakan suatu pandangan seseorang tentang kesesuaian harga terhadap produk dan harga produk terhadap kemampuan finansial untuk mendapatkan produk tersebut (Schiffman \& Kanuk, 2007a). Dikarenakan persepsi harga setiap orang berbeda-beda, maka dari itu pemasar harus dapat menentukan dengan sesuai harga dengan produk dan memberikan saran yang sesuai dan memiliki solusi yang tepat bagi para calon konsumennya.

Consumer perceptions of a price can influence decisions in buying or using a product, so that a company must be able to provide a good perception of the products or services they sell. According to Amanah et al. (2018), perception is an individual's process of selecting, organizing, and translating incoming information stimuli into a comprehensive picture. Therefore, perception has a powerful influence on consumers. One of the factors that influence consumers is the perception of price. Kotler \& Keller (2012) state that price is the amount of money charged for a product or the sum of the value consumers exchange for the benefits of having or using the product 
or service.

An instant lifestyle that prioritizes the value of practicality, speed and time efficiency is now the choice of many people. For some people, fast, practical and efficient has become an essential requirement in their daily activities. This certainly affects business competition, which is then responded to by producers to design products that follow market needs followed by good and guaranteed product quality at an acceptable price in the market so that it becomes a consumer consideration in determining purchasing decisions (Akhmedova et al., 2020). The marketing parties must carefully consider deciding on a purchase at the stage of purchasing decisions, problem recognition, information search, alternative evaluation, purchase decisions, and consumer post-purchase behaviour. The importance of understanding purchasing decisions is that it can be a reference for managers to move actively and for sales to serve consumers well, provide appropriate and helpful information and provide the right solutions to win the hearts of potential buyers.

This study has several empirical contributions as follows (1) emphasizing the observation of external causes that influence purchasing decisions; (2) expand the research results specifically and observe the influence of social media, price perceptions and consumer buying interest; (3) the findings of this research can be used as the basis for formulating marketing strategies; and (4) improve the ability to generalize research on the determinants of purchasing decisions, especially in online purchases.

\section{LITERATURE REVIEW}

\section{Purchase decision}

The consumer's purchase decision is to buy the most preferred brand from various alternatives, but the buying decision has two factors between purchase intentions and purchase decisions (Amstrong \& Kotler, 2008). Cordova et al. (2020) define a decision as choosing between two or more alternative actions or behaviours. Decisions always require a choice between different behaviours. Therefore, decisions always need a choice between other behaviours. Furthermore, Amstrong \& Kotler (2008) defines consumer purchasing decisions as buying the most preferred brand from various alternatives, but two factors can be between purchase intentions and purchase decisions. The first factor is the attitude of others and the second factor is the situational factor. Meanwhile, according to Chao \& Jiaming (2014), the purchase decision is a process in an actual purchase, whether to buy or not.

Schiffman \& Kanuk (2007b) generally say that a decision is a choice of two or more alternatives; on the other hand, if a consumer does not have an option, it is not categorized as decision making. According to Kotler \& Keller (2016), the buying decision process begins when the buyer realizes a need problem. Then, the buyer acknowledges there is a difference between the actual condition and the desired condition. After that, a consumer whose interest begins to arise will be motivated to seek more information to get a collection of brands with various features.

After purchasing the product, consumers will experience a certain level of satisfaction or dissatisfaction. Consumers will show positive attitudes and behaviour towards the products or services they buy if they are satisfied. Consumers will likely buy again, are loyal or even do not hesitate to recommend to others; on the contrary, if consumers are disappointed, they tend to have a negative attitude, stop the next purchase or tell unpleasant things about the product or service they bought to other consumers. Thus, consumer satisfaction or dissatisfaction with a product will affect subsequent behaviour. Furthermore, according to Chao \& Jiaming (2014), the general steps in making a purchase include the introduction of needs, information search, evaluation of alternatives, purchase decisions, and post-purchase behaviour.

Consumer behaviour will determine the decision-making process in their purchase; a function is a problemadjusting approach consisting of five stages carried out by consumers: problem recognition, information search, alternative assessment, decision making, and post-purchase behaviour (Kotler, 2000).

Purchasing decision indicators used in a purchase decision, according to Kotler \& Keller (2012)) are: (1) Stability in a product, (2) Habits in buying products, (3) Providing recommendations to others (4) Re-purchase.

\section{Purchase Interest}

Buying interest is the attitude of consumers who are interested and then take actions related to purchases through various stages and levels of possibility up to the ability to buy certain products, services or brands. Buying interest is a consumer's tendency to buy a brand or take action related to a purchase which is measured by the probability that consumers make a purchase (Japarianto \& Adelia, 2020). According to Kotler \& Keller (2009), buying interest is something that arises after receiving a stimulus from the product he sees; from there, an interest arises to try the product until finally the desire to buy it arises to have it. Meanwhile, Schiffman, L. G., \& Kanuk (2010) stated that buying interest is a model of a person's attitude towards the object of goods suitable for measuring attitudes towards certain groups of products, services, or brands.

According to Kotler (2005), ) interest is described as a situation where consumers have not taken action, which can be used as a basis for predicting that behaviour or activity. Interest is a behaviour that appears in response to an object that shows the customer's desire to purchase. Saleem \& Ellahi (2017) argue that buying interest is the emergence of a desire in consumers for a product due to the consumer's observation and learning process for the 
product. Purchase intention is the tendency to feel attracted or compelled to carry out activities to obtain and have goods and services. Buying interest is a consumer mental statement that reflects the purchase plan with a particular brand (Japarianto \& Adelia, 2020). Meanwhile, according to Baskaran et al. (2017), buying interest is the stage of the consumer's tendency to act before the buying decision is implemented. In line with Kim \& Hyun (2011), who argue that buying interest is related to consumers' plans to purchase certain products and how many units of product are needed in a certain period.

From some expert opinions above, it can be concluded that buying interest is a statement in consumers that shows a consumer's tendency or interest to buy a product in a certain amount and a certain period that marketers can use to predict customer desires. Buying interest arises after the alternative evaluation process. In the evaluation process, a person will make a series of choices about the product to be purchased based on brand and interest (Kotler, 1999).

Purchase interest is the last stage of a complex buying decision process. This process starts from the emergence of the need for a product or brand), then information processing by consumers, consumers will evaluate the product or brand. This evaluation ultimately leads to an interest in buying before the consumer makes a purchase. Some aspects of buying interest according to Schiffman \& Kanuk (2007b) are (1) Interested in finding information about the product., (2) Considering buying., (3) Interested in trying., (4) Wanting to know the product., (5) Want to own the product.

\section{Social media}

Social media is a means for consumers to share text, image, video, and audio information with each other and with companies and vice versa (Kotler \& Keller, 2016)). Social media is online media where users can easily participate, share and create content, including blogs, social networks, wikis, forums, and virtual worlds. Social media itself can have a positive or negative function, depending on its use. Social media is just a new set of tools, new technologies that make us more efficient in connecting and building relationships with existing customers and prospects.

Social media now has an essential role in marketing strategies for small and large businesses (Appel et al., 2020). Now sharing information with visitors or followers is not the only advantage of using social media for a business. Social media is used to find other people who become friends or find friends who have lost contact. Over time, social media has finally transformed into a medium that is used for business purposes.

Marketing through social media is a marketing process carried out through a third party, namely a social media-based website (Bail et al., 2018). Currently, many social media can be used for marketing or promoting a product or service. Marketing with social media is not always related to buying and selling directly. In this marketing, you can market content in posts on the web, images or videos. Content that is marketed through social media is related to the product to be sold. Apart from marketing content, this modern marketing technique is also used to market brands. The purpose of marketing the brand here is to introduce the brand in general to the community or what is often referred to as brand awareness.

Social media often used for marketing or promotion include Facebook, Instagram, and Twitter (Allcoot et al., 2014). Through this media, companies or brands can carry out structured and targeted advertisements. One of the popular social media used in social media marketing is Instagram. Instagram is a photo-sharing application that is being loved lately. Instagram has power in the visual field. The advantage of Instagram as a marketing tool is that Instagram can convey messages from a brand through photos/images or videos 15 seconds long. Instagram is no longer present as a selfie-platform or a social media for virtual worlds but has become a new alternative in launching marketing action.

One of the keys to success for all businesses is getting to know their customers better (Bail et al., 2018). Social media makes this recognition process more accessible than ever before. With existing supporting tools using social media, you can find out in detail about who the consumers are, the language they use, age range, and even gender. This information can help the process of branding and promotion to the right target consumers.

Business people see that internet users become easy targets for their future business. In this era, more and more people are using social media. Seeing the increasing number of users, social media can increase profits and expand business wings.

Digital marketing has become a trend in the internet era (Appel et al., 2020). Brand owners are starting to use social media as a new promotion and marketing medium. Social media has changed how consumers interact and how companies market products. Social networking sites are a good business opportunity to market or promote the products to be sold.

The advantages of marketing through social media include communicating with consumers, as a media for collaborating in the event of consumer dissatisfaction, as a promotional medium, and building a brand (Bail et al., 2018). However, in creating a perception in consumers' thoughts about a product, service or brand, careful thought is needed on what promotional media is suitable and effective so that the perception and image to be conveyed can be firmly attached to other similar products or brands. 
There are much promotional media that can be used, ranging from the general to the unique or new; until now, they have been used as promotional media, which was quite effective in acquiring new potential customers (Allcoot et al., 2014). Several fields can use social media to introduce their products/services/brands. Business owners or companies ogle the widespread use of social media by the Indonesian people to market their products or services. Advertisements that we used to only see in conventional media such as television, radio, newspapers or magazines have now spread to the world of social media. Social media has now become a platform to market products and has been used by leading brands such as Starbucks, Nike, Dell and so on.

\section{Price Perception}

Price is one of the tools that marketers can use to face the market, either directly by attracting and retaining clients or against competitors (Widyastutir \& Said, 2017). In a product, the price is an indicator to determine the quality of a product or service itself, thus making a price a measuring tool to assess its quality. According to Kotler \& Amstrong (2007), price is the sum of all values exchanged by consumers for the benefits of using the product or service. According to Kotler \& Keller (2009), price is the number of money customers has to pay for the product. According to Akhmedova et al. (2020), price is the way buyers perceive the price of a product, which ultimately affects consumer's desire to buy a product, while perception is the process by which people select, organize and interpret the benefits associated with the product (Lin et al., 2017). So what is meant by price perception is whether the price of a product is high or cheap (Larson, 2014).

According to Amstrong \& Kotle (2008), price perception is the tendency of consumers to use price in assessing the suitability of the benefits of a product, while according to McRae \& Meeks (2016), price perception is how price information is understood by consumers and made meaningful to them. Therefore, it can be said that the perception of price varies from one individual to another. Price perception is a view of the perception or price of the price how customers perceive a specific price (high, low, reasonable) has a strong influence on purchase intention and purchase satisfaction(Schiffman \& Kanuk, 2008).

In cognitive processing of price information, consumers can compare the stated price with a price or price range that they imagine for the product. The price that is considered as the material for making the comparison is called the internal reference price. Internal reference prices are prices that consumers consider reasonable, which have existed historically, or that consumers imagine to be high or low market prices. The internal reference price becomes a guide to evaluate whether the listed price is acceptable to consumers.

According to Schiffman \& Kanuk (2007b), price is one element of the marketing mix that requires careful consideration. This is due to several strategic dimensions of price in terms of (1) Price is a statement of the value of a product; (2) Price is an aspect that is obvious to buyers; (3) Price is the primary determinant of demand; (4) Prices are flexible; (5) Price affects image and positioning strategy; (6) Price is a problem that a manager must face.

The indicators used for price perception, according to Kotler \& Keller (2009), are: (1) Price affordability, (2) Price compatibility with product quality, (3) Price competitiveness, (4) Price compatibility with benefits

\section{METHODOLOGY RESEARCH}

The population in this study are all online purchasing consumers in Indonesia. The population is categorized as an infinite population by considering the number of populations that cannot be known with certainty. Considering the nature of the population and geographic area, the sampling technique uses non-probability sampling. This technique has the characteristic that each member of the population does not have the same opportunity to be taken as a sample (Kerlinger, 1992). In this study, the model was taken using the accidental sampling method, a technique for determining the example that the researcher met by chance if it is deemed that the person is suitable as a data source. Of the 280 respondents involved in this study, only 260 were included in the analysis.

Table 1. Test Results Validity and Reliability of Research Instruments

\begin{tabular}{|c|c|c|c|}
\hline Variable/Indicator & $\begin{array}{c}\text { Corrected Item-Total } \\
\text { Correlation }\end{array}$ & Cronbach Alpha & Status \\
\hline $\begin{array}{l}\text { Social media } \\
\text { Provide complete information } \\
\text { Attract consumers' attention } \\
\text { Build communication with consumers } \\
\text { Maintain post-purchase interactions }\end{array}$ & $\begin{array}{l}0,572 \\
0,767 \\
0,792 \\
0,677\end{array}$ & 0,992 & $\begin{array}{l}\text { Reliable } \\
\text { Valid } \\
\text { Valid } \\
\text { Valid } \\
\text { Valid }\end{array}$ \\
\hline $\begin{array}{l}\text { Price Perception } \\
\text { Price affordability } \\
\text { Compatibility with purchasing power } \\
\text { Conformity with quality } \\
\text { Suitability with benefits } \\
\text { Competitiveness between products }\end{array}$ & $\begin{array}{l}0,595 \\
0,325 \\
0,653 \\
0,777 \\
0,628\end{array}$ & 0,884 & $\begin{array}{l}\text { Reliable } \\
\text { Valid } \\
\text { Valid } \\
\text { Valid } \\
\text { Valid } \\
\text { Valid }\end{array}$ \\
\hline
\end{tabular}




\begin{tabular}{|c|c|c|c|}
\hline Variable/Indicator & $\begin{array}{l}\text { Corrected Item-Total } \\
\text { Correlation }\end{array}$ & Cronbach Alpha & Status \\
\hline $\begin{array}{l}\text { Purchase Interest } \\
\text { Looking for as much information as possible } \\
\text { Want to know the products offered } \\
\text { Interested in trying using the product } \\
\text { Tend to want to buy the product }\end{array}$ & $\begin{array}{c}0,636 \\
0,647 \\
0,634 \\
0,684\end{array}$ & 0,848 & $\begin{array}{l}\text { Reliable } \\
\text { Valid } \\
\text { Valid } \\
\text { Valid } \\
\text { Valid }\end{array}$ \\
\hline $\begin{array}{l}\text { Purchase decision } \\
\text { Bought because the product is quality } \\
\text { Accepted for my own will } \\
\text { But because it's better than competitors' } \\
\text { products } \\
\text { Bought it because the product is hygienic } \\
\text { Feel confident purchasing the products } \\
\text { offered }\end{array}$ & $\begin{array}{l}0,798 \\
0,493 \\
0,847 \\
\\
0,760 \\
0,835\end{array}$ & 0,916 & $\begin{array}{c}\text { Reliable } \\
\text { Valid } \\
\text { Valid } \\
\text { Valid } \\
\\
\text { Valid } \\
\text { Valid }\end{array}$ \\
\hline
\end{tabular}

\section{RESULT AND DISCUSSION}

As explained earlier, 260 respondents were involved in the research and deserved further analysis. Of the respondents involved, most (64\%) were women, and the rest were men. Some are between 20 and 30 years old, and the rest are over 30 years old. In terms of employment, most (58.4\%) are private employees, the rest work as students and civil servants.

Then used Structural Equation Modeling (SEM) and AMOS 24.0 program to test the hypothesis of this research. The effect of exogenous variables on endogenous variables and the t value of each result looks like in Figure 2. The statistical significance of the final structural model shows that the model is very good (fit) in representing the data of this study. This is evidenced by the X2 value of 150.208 and the probability value $=0.088$ with a degree of freedom of 393, then the Normed X2 $=1.173$, which means that the model has a good level of conformity. This fact is reinforced by the RMESEA value of 0.035 and the TLI value $=0.980$, and the CFI $=0.983$. This indicates that this research model can be replicated in similar samples in the same population. The regression coefficients and the significance of the influence between variables and the hypothesis testing of this study are shown in Tables 2 and 3.

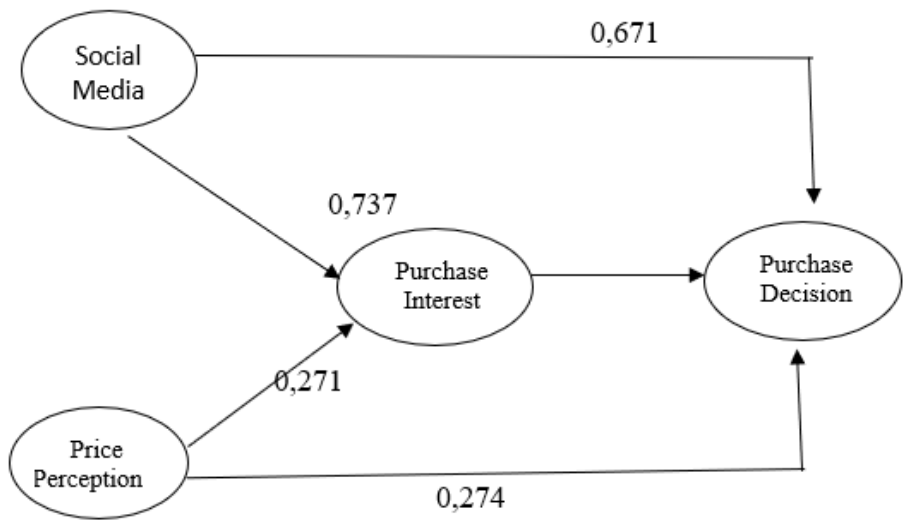

Figure 2: Structural Model

Table 2: Regression Coefficient

\begin{tabular}{|l|c|c|c|c|}
\hline Regression Path & $\begin{array}{c}\text { Regression } \\
\text { Coefficient }\end{array}$ & $\begin{array}{c}\text { Standard } \\
\text { Error }\end{array}$ & $t$-value & Prob. \\
\hline $\mathrm{PP} \rightarrow \mathrm{PI}$ & 0,271 & 0,060 & 4,536 & 0.0001 \\
\hline $\mathrm{SM} \rightarrow \mathrm{PI}$ & 0,737 & 0,119 & 6,193 & 0.0001 \\
\hline $\mathrm{PP} \rightarrow \mathrm{PD}$ & 0,274 & 0.053 & 5,152 & 0.0001 \\
\hline $\mathrm{PI} \rightarrow \mathrm{PD}$ & 0,438 & 0,111 & 3,954 & 0.0001 \\
\hline $\mathrm{SM} \rightarrow \mathrm{PD}$ & 0,671 & 0,122 & 5,495 & 0.0001 \\
\hline \multicolumn{5}{|l}{} \\
\hline
\end{tabular}


Table 3. Hypothesis Test Results

\begin{tabular}{|l|c|c|c|c|}
\hline \multicolumn{1}{|c|}{ Hypothesis } & $\begin{array}{c}\text { Direction } \\
\text { Influence }\end{array}$ & $\begin{array}{c}\mathrm{t}- \\
\text { value }\end{array}$ & Prob. & Information \\
\hline H1: Social media has a positive effect on purchasing decisions & + & 5,495 & 0.0001 & Accepted \\
\hline H2: Social media has a positive effect on purchase interest & + & 6,193 & 0.0001 & Accepted \\
\hline H3: Price perception has a positive effect on buying interest & + & 4,536 & 0.0001 & Accepted \\
\hline $\begin{array}{l}\text { H4: Price perception has a positive effect on purchasing } \\
\text { decisions }\end{array}$ & + & 5,152 & 0.0001 & Accepted \\
\hline $\begin{array}{l}\text { H5: Purchase interest has a positive effect on purchasing } \\
\text { decisions }\end{array}$ & + & 3,954 & 0.0001 & Accepted \\
\hline
\end{tabular}

Source: Processed SEM data (2021)

From the model testing results, all variables are variables that qualify as variables that support the research model. Data analysis and hypothesis testing show that data support all hypotheses in this study. The supported thesis shows that the findings follow the existing theory. The results show that social media and price perception have a direct effect on purchasing decisions. In addition, social media and price perceptions indirectly impact purchasing decisions through the mediation of buying interest.

The regression coefficient of the influence of social media shows that social media has more effect on buying interest than the influence of social media on purchasing decisions. This finding illustrates that when the social media used is more diverse, at the same time, consumer buying interest also increases. This finding is in line with the research results of Bail et al. (2018) and Appel et al. (2020). Finally, the regression coefficient of the effect of price perception shows that price perception has more influence on purchasing decisions than price perception on buying interest. This finding illustrates that when the price is perceived well by consumers, at the same time, purchasing decisions increase. This finding is in line with the research results of Akhmedova et al. (2020) and Widyastutir \& Said (2017).

The regression coefficient of the influence of social media on purchasing decisions through the mediation of buying interest shows a significant effect. This finding indicates that diverse social media will increase buying interest which in turn will increase purchasing decisions. This finding supports the research results (Bail et al., 2018) (Appel et al., 2020). Likewise, the regression coefficient of the effect of price perception on purchasing decisions through the mediation of buying interest shows a significant impact. This finding indicates that price perception will increase buying interest which in turn will increase purchasing decisions. (Akhmedova et al., 2020) (Widyastutir \& Said, 2017).

\section{CONCLUSION AND SUGGESTIONS}

Overall, the results of this study illustrate that online purchasing decisions are not only determined by social media and price perceptions directly but are also determined by buying interest that mediates social media and price perceptions. Social media has more influence on purchase intention than purchase decision, while price perception influences purchase decision than purchase intention.

This study has several weaknesses that need to be overcome for researchers interested in researching online purchasing decisions, especially regarding the selection of research subjects. Like several previous studies, this research was conducted on Shopee online shop consumers to represent the online market in Indonesia. To obtain findings that can be generalized in the online market, further research needs to use other marketplaces to test the consistency of the results.

\section{REFERENCE}

Akhmedova, A., Marimon, F., \& Mas-Machuca, M. (2020). Winning strategies for customer loyalty in the sharing economy: A mixed-methods study. Journal of Business Research, 112(May 2019), 33-44. https://doi.org/10.1016/j.jbusres.2020.02.046

Allcoot, H., Braghieri, L., Eichmeyer, S., \& Gentzkow, M. (2014). 済無No Title No Title No Title. Paper Knowledge. Toward a Media History of Documents.

Amanah, D., Hurriyati, R., Gaffar, V., Layla, A. A., \& Harahap, D. A. (2018). Effect of Price and Product Completeness on Consumer Purchase Decision at Tokopedia.com. December, 34-37. https://doi.org/10.5220/0007114300340037

Amstrong, G., \& Kotler, P. (2008). Prinsip-prinsip pemasaran. Jakarta: Erlangga.

Appel, G., Grewal, L., Hadi, R., \& Stephen, A. T. (2020). The future of social media in marketing. Journal of the Academy of Marketing Science, 48(1), 79-95. https://doi.org/10.1007/s11747-019-00695-1

Bail, C. A., Argyle, L. P., Brown, T. W., Bumpus, J. P., Chen, H., Fallin Hunzaker, M. B., Lee, J., Mann, M., Merhout, F., \& Volfovsky, A. (2018). Exposure to opposing views on social media can increase political polarization. Proceedings of the National Academy of Sciences of the United States of America, 115(37), 
9216-9221. https://doi.org/10.1073/pnas.1804840115

Baskaran, S., Ayob, S. A., Howe, N. C., \& Mahadi, N. (2017). Understanding Purchase Intention of Ready-to-Eat Food among Malaysian Urbanites: A Proposed Framework. International Journal of Academic Research in Business and Social Sciences, 7(11). https://doi.org/10.6007/ijarbss/v7-i11/3496

Chao, W., \& Jiaming, F. (2014). The role of E-quality within the consumer decision-making process. International Journal of Operations and Production Management, 34(12), 1506-1536. https://doi.org/10.1108/IJOPM-072013-0352

Cordova, G. I., Guerreros, D. R., Surichaqui, S., Ricaldi, D. P. I., Fiorella, V. R., Vicente-Ramos, \& Wagner. (2020). Impact of visual merchandising on the purchase decision of consumers from retail stores in central Peru. Management Science Letters, 10(11), 2447-2454. https://doi.org/10.5267/j.msl.2020.4.005

Japarianto, E., \& Adelia, S. (2020). Pengaruh Tampilan Web Dan Harga Terhadap Minat Beli Dengan Kepercayaan Sebagai Intervening Variable Pada E-Commerce Shopee. Jurnal Manajemen Pemasaran, 14(1), 35-43. https://doi.org/10.9744/pemasaran.14.1.35-43

Kim, J. H., \& Hyun, Y. J. (2011). A model to investigate the influence of marketing-mix efforts and corporate image on brand equity in the IT software sector. Industrial Marketing Management, 40(3), 424-438. https://doi.org/10.1016/j.indmarman.2010.06.024

Kotler, P., \& Keller, K. L. (2009). Marketing management (13th ed.). In Prentice Hall.

Kotler, P. (2000). Marketing management, Millenium edition. Marketing Management. https://doi.org/10.1016/0024-6301(90)90145-T

Kotler, Philip. (1999). MANAJEMEN PEMASARAN DI INDONESIA: Analisis, Perencanaan, Implementasi dan Pengendalian, buku satu.

Kotler, Philip. (2005). The role played by the broadening of marketing movement in the history of marketing thought. Journal of Public Policy \& Marketing, 24(1), 114-116.

Kotler, Philip, \& Amstrong. (2007). Principle of Marketing. Prentice Hall International Inc, New Jersey.

Kotler, Philip, Kartajaya, H., \& Setiawan, I. (2019). Marketing 3.0: From products to customers to the human spirit. In Marketing Wisdom (pp. 139-156). Springer.

Kotler, Philip, \& Keller, K. L. (2009). Dirección de marketing. Pearson educación.

Kotler, Philip, \& Keller, K. L. (2012). Marketing Management. Pearson.

Kotler, Philip, \& Keller, K. L. (2016). Marketing Management MARKETING MANAGEMENT Marketing Management. In Marketing Management.

Larson, R. B. (2014). Psychological Pricing Principles for Organizations with Market Power. Journal of Applied Business and Economics, 16(1), 11-25.

Lin, Y. C., Lee, Y. C., \& Wang, Y. F. (2017). The International Journal of Organizational Innovation. 10(2), 1323.

McRae, S., \& Meeks, R. (2016). Nkfcm. Working Paper, September, 1-42. http://www.robynmeeks.com/wpcontent/uploads/2016/01/price-perception-electricity-Sept2015.pdf\%5Cnhttp://www.econthatmatters.com/2016/06/aere-summer-conference-papers-on-developingcountries/\#more-994

Miarso, Y. (2007). Menyemai Benih Teknologi Pendidikan. In Computer.

Saleem, A., \& Ellahi, A. (2017). www.econstor.eu.

Schiffman, L. G., \& Kanuk, L. L. (2010). Consumer Behavior, 9th Edition. In South-Western Thomas Learning. Mason, $\mathrm{OH}$.

Schiffman, \& Kanuk, L. L. (2007a). Perilaku Konsumen,.(dialihbahasakan oleh Zulkifli \& Kasip, Eds.)(Ketujuh.). $P T$. Indexs.

Schiffman, L., \& Kanuk, L. L. (2007b). Perilaku Konsumen Edisi Kedua. In PT. Indeks Gramedia.

Schiffman, L., \& Kanuk, L. L. (2008). Perilaku konsumen edisi ketujuh. Jakarta (ID): PT Index Group.

Widyastutir, S., \& Said, M. (2017). Consumer consideration in the purchase decision of SPECS sports shoe products through brand image, product design and price perception. International Journal of Supply Chain Management, 6(4), 199-207. 